\title{
Taxation of the financial sector: Is a bank levy the answer to the financial crisis?
}

\author{
Karolina Puławska ${ }^{1}$ (D)
}

Accepted: 2 August 2021 / Published online: 14 August 2021

(c) The Author(s), under exclusive licence to Springer Nature Limited 2021

\begin{abstract}
To reduce the probability of financial crises, policymakers have introduced bank levies, whose application differs across countries. The problem in their use lies in identifying the most effective regulatory instruments to reduce risk. Our study might be of interest to various researchers and professionals, as we discuss the significance of research on bank levies with respect to theory and economic practice and then propose models of banking sector taxation and directions for future research. Moreover, this paper presents the history of taxation of the financial sector, the models introduced in different European countries, the advantages and disadvantages of each of the possible solutions, the results of studies on the impact of the new levy on the behavior of the financial sector and recommendations for how the levy should be structured.
\end{abstract}

Keywords Bank levy · Regulations · Taxation · Banking crisis

JEL Classification G010 · G2 · G28

\section{Introduction}

The global financial crisis (GFC) of 2007-2008 has shown that banks' risky operations might have dramatic consequences for economies for the following reasons: First, banks can incur great losses and spend a considerable amount of public resources on bailing them out, and second, bank bankruptcies have major social and economic consequences throughout the world [79]. Furthermore, recessions triggered by debt crises are particularly severe and long-lasting [89]. Moreover, the GFC has provided overwhelming evidence confirming the importance of the effective functioning of the banking sector. The bankruptcy of Lehman Brothers in 2008 , along with the "freezing" of the interbank market, has led to the bankruptcy of numerous banks that were unable to acquire funding in the market. These events are even more serious because the financial sector as a proportion of the overall economy in many countries has grown in addition to becoming globalized [82]. Therefore, GFC highlighted the

Karolina Puławska

k.pulawska@kozminski.edu.pl

1 Koźmiński University, ul. Jagiellonska 57/59, 03-301 Warsaw, Poland pivotal role of a properly functioning money market for both monetary policy and financial stability [35].

When G20 leaders met at Pittsburgh in 2009 to discuss the ongoing financial crisis, they requested the International Monetary Fund (IMF) to investigate how the financial sector can make substantial contributions toward relieving any burden associated with government interventions to repair the banking system [45]). Hence, policymakers proposed several means to increase revenues from the financial sector through levies on financial institutions and additional tax instruments [44, 62]. Many proposals have been advanced regarding ways to protect the banking sector from future turbulences and discouraging banks from taking unnecessary risk. One of the proposals, which are heavily debated these days, is the introduction of taxes in the financial sector (International Monetary Fund, 2010). Taxing the financial sector could serve as a lever in regulating it without direct intervention [31]. Therefore, taxation can be considered as a measure to counteract the negative externalities generated by the financial sector, especially during economic crises, but also before and after them [58].

The proponents of this reform suggest three types of taxes: 
a. Financial stability contribution (bank levy) levied on specific components of balance sheets of financial institutions.

b. Financial activities tax (FAT) levied on the total profits of financial institutions.

c. Financial transaction tax (FTT) levied on a specific type of financial transaction for a particular purpose.

They argue that, designed as a Pigouvian tax,${ }^{1}$ taxing short-term funding, with the exception of stable funding, such as equity and deposits will discourage banks from undertaking risky activities [13, 24, 49]. Just like a Pigouvian tax, bank levies put a price on the bank's contribution to systemic risk and thus, aim at internalizing negative externalities. The bank's contribution to the systemic risk depends, first and foremost, on its leverage, size and degree of interconnectedness with financial system [40, 54]. It has been argued that the aim of bank levies is to modify the incentives of banks' management and owners to persuade them to consider their bank's contribution to systemic risk [7]. Others claim that bank levies allow taxing potential economic rents enjoyed by the financial sector owing to implicit and explicit state guarantees [15]. Moreover, additional levies can also offset tax distortions, as financial services are exempt from value-added tax (VAT) and used for fiscal optimization [42]. In addition, systemically important banks benefit from implicit government guarantees. The government might be inclined to bail out bank creditors, as winding up a systemically important bank generates the risk of destabilizing the entire financial system. This implicit guarantee creates incentives for banks to become systemically important [91]. If the aim of the regulation is to withdraw implicit guarantees, winding down even systemically important banks must become feasible. The proceeds that are collected through bank levies thus contribute to a fund that ensures sufficient liquidity to initiate the restructuring and resolution of ailing banks and the bail-in of creditors [8].

Many countries have decided to apply this regulatory instrument, despite the difference in taxation schemes applied by them. For example, European Union member states, such as Austria, Belgium, Cyprus, Denmark, Germany, the Netherlands, Latvia, Portugal, Romania, Slovakia, Sweden and the UK have decided to introduce a bank levy on bank liabilities, while Poland, Slovenia, Finland and Hungary apply one to bank assets. France has chosen to levy bank capital. Although levy design has been subject to legislative debates, an increasing number of countries are considering its introduction.

\footnotetext{
${ }^{1}$ An idea introduced by Pigou [71], who generally argued that, when externalities are present, indirect taxation can be used as a tool for correcting inefficiencies in the competitive allocation of resources.
}

The recent trend of levying taxes on bank operations has raised the question of its impact on the performance and activity of domestic banking systems. Taxing bank operations could disrupt bank activities and negatively affect countries' economic situation. Many economists, credit rating agencies and bankers have warned against the negative consequences of introducing a bank levy. In particular, a bank levy on bank assets has been strongly criticized in the media. For instance, the European Central Bank argues that a proposed bank levy can have negative consequences for the provision of credit and financial stability and thus should be analyzed thoroughly before introducing it. This can give financial institutions an incentive to change their risk profile by restructuring their portfolios in favor of riskier products by making use of off-balance sheet activities and/ or transferring their assets abroad [29]. Moreover, previous research has shown that a bank levy on assets might have a negative impact on the liquidity of the interbank market $[74,75]$, when interbank positions were not excluded from the tax base.

Taxing the financial sector has a number of practical difficulties, such as defining the tax rate, the taxable base and the object, categories of taxpayers and the scope and place of taxation [58]. For example, the IMF [45] is concerned with the pass-through effect and a negative effect on bank asset growth, as a reduction in after-tax returns inhibits expansion. The research results referred in this article support these expectations $[9,51,76]$. Additionally, the IMF has pointed out a number of problems, questioning how the new tax affects lending and growth. The European Union has also expressed concern about the tax proposed by governments, claiming that it could weaken banks and prove detrimental to both the investment climate and economic growth [69]. The extant literature exploring the role of financial sector taxes is very scarce. Several questions remain unresolved: Does the financial sector fulfill its role? How does it affect banking operations? Which tax format is the most effective from the perspective of regulators? Which structure of bank levy is the most harmful for the banking sector? Answering these questions, which are still intensely debated, is crucial. Therefore, in this paper, we show the weaknesses and strengths of additional taxation of the banking sector, recall the history of additional taxation of the financial sector and present different possible models of taxation, which were introduced in Europe after the GFC. The article makes a valuable contribution, because currently, in the turbulent circumstances caused by the COVID-19 pandemic, the topic of additional taxation of the banking sector is very important from the point of view of regulators. For example, the Hungarian government is currently engaged in a debate regarding whether a one-off tax on the banking sector that will bolster Hungary's pandemic war chest can be deducted in full from the bank levy over the subsequent five years [68]. 
This article is an overview of new taxes introduced in the European banking sector after the financial crisis of 2007-2008. The remainder of the paper proceeds as follows. The next section present history and models of additional taxes in financial sector, review of the literature, the significance of bank levy for economic practice and the assessment of the models of bank levy. The third section concludes.

\section{Taxation of the financial sector}

\section{History of taxation of financial sector}

The taxation of the financial sector is not an entirely new concept. It has been explored in several studies. For example, Hillman et al. [41] recall that, in 1694, registered transaction charges first took the form of a state tax levied by the London Stock Exchange. The tax share was paid by the buyer and the purchase and sale document was sealed by an official stamp that was required for the conclusion of a purchase transaction. This British stamp tax is considered one of the earliest instances of FTT. The value of this tax depended on stock transfers, which were made legally enforceable only with an official stamp [11]. Then, the USA introduced a stock transaction tax between 1914 and 1965, as did New York State from 1905 to 1981. An FTT was put in place during the 1920s. Regardless of its other effects, it did not curb speculation enough to avert the stock market crash of 1929 [90]. Its initial rate was 0.02 percent of the stock's par value (i.e., the value stated in the charter, which is usually lower than the current market value). In 1932, the tax was increased and it reached a level between 0.04 and 0.06 percent, depending on the type of transaction [10]. In 1934, the Securities Exchange Act granted the Securities and Exchange Commission the authority to fund its oversight operations with fees imposed on self-regulatory bodies, such as the New York Stock Exchange [81].

A new concept of financial taxation was created after the Great Depression of the 1930s, which evolved over the years. The idea of taxing the financial sector after the Great Depression was advanced by Keynes [50]. He proposed the introduction of a tax on capital transactions in the stock market. He argued that this would help reduce the scale of speculation. Tobin (1974) recommended the implementation of a tax on the purchase of foreign currencies and securities in foreign currencies to limit currency fluctuations. In 1936, during the Great Depression, Keynes advocated a wider application of FTT. He proposed a small transaction tax on all Wall Street transactions in the USA and claimed that an excessively high speculation level is the result of illconsidered actions taken by financial traders. Keynes was concerned about the proportional distribution of financial speculators within the market and the likelihood of their dominance if they remain unchecked [52].

After the breakdown of the Bretton Woods system in the early 1970 s, financial sector taxation attracted the attention of economists and regulators. Tobin [46] proposed an internationally uniform tax on all spot conversions of one currency into another. Moreover, he suggested that the tax would prove particularly effective in deterring short-term financial round-trip excursions into another currency. It was one of the measures that protect businesses from the conversion bubble. Set at $0.5 \%$ of the transaction value, Tobin tax was originally defined as a tax on all foreign exchange spot transactions. The tax was imposed on short-term currency conversions. It played an important role in 1971 when the US dollar could no longer be converted into gold, as per the Bretton Woods system. Faith in the dollar wavered and the Bretton Woods system collapsed. Tobin tax became an instrument of foreign exchange protection and subsequently served as the basis for various projects related to the taxation of financial assets in different countries.

In recent decades, individual citizens have taken out loans at their own risk to pay for their education or their advancement to a less destitute urban neighborhood. The government to a minor degree funded equal access to decent housing or the formation of marketable work skills. Therefore, what we have witnessed over the past few decades is not the retreat of the state at the behest of the market, but rather the emergence of an altogether different type of state intervention [93]. Crouch [21] has coined the term "privatized Keynesianism" to describe the Anglo-American policy regime in which citizens, not governments, take on debt to stimulate the economy. Therefore, the GFC was very painful not only for bankers, but also for individual citizens who lost their savings or homes as a result of the crisis.

\section{Taxation of the financial sector after GFC}

Although the concept of FTT can be traced back to Keynes [50] and Tobin [46], it has received renewed attention among regulators, especially in Europe, as a result of the GFC of 2007-2008 [14]. During the GLC, about 700 employees of Merrill Lynch received bonuses in excess of $\$ 1$ million in 2008 from a total bonus pool of $\$ 3.6$ billion, in spite of the fact that the firm lost $\$ 27$ billion [67]. One of the most egregious examples of perverse incentives can be found in insurance giant AIG's Financial Products unit. This division, which gambled on credit default swaps, contributed substantially to AIG's rising profits in the boom. In 2008, the unit lost $\$ 40.5$ billion. Though the US government owns $80 \%$ of AIG's shares and invested $\$ 180$ billion in the corporation, AIG nevertheless paid the 377 members of the division a total of $\$ 220$ million in bonuses for 2008 [72]. These examples show that it is rational for top financial firm 
operatives to take excessive risk in the bubble, even if they understand that their decisions are likely to cause a crash in the intermediate future. Since they do not have to return their bubble-year bonuses when the inevitable crisis occurs and since they continued to receive substantial bonuses even during the crisis, they have a powerful incentive to pursue high-risk, high-leverage strategies [20]. Therefore, the crisis has once again highlighted the need to reduce short-term speculative transactions and increase the resilience of the financial system [66], bringing financial sector taxation to the fore. From the beginning, special taxes on the financial sector had many advocates, including political and economic leaders, civil society organization and financiers.

Primarily, taxes on financial institutions were introduced to compensate for the consequences of the financial crisis (e.g., [70, 87]), followed by the exemption of the majority of financial services from VAT $[12,13,52,58,64,78]$. Taxes on financial institutions were also introduced to increase public revenue (e.g., $[27,58,60])$. It is generally asserted that the financial sector has contributed greatly to the crisis and received generous government support through fees paid by taxpayers over the past several years [58]. To ensure a fair contribution by the sector to public finances and for the benefit of the citizens, the European Commission has put forward several proposals of financial sector taxation. Many hold the opinion that, given its responsibility for global economic downturn, the financial sector ought to bear the fiscal costs of the crisis [60].

There are opponents and proponents of the imposition of taxes on financial institutions after the GFC. Countries unwilling to take such measures argue that they would damage the competitiveness of financial institutions, increase prices of financial products and interest on loans and reduce demand for labor in the financial sector [53]. Opponents argue that such regulations could:

a. have negative institutional consequences for banks, including:

i. dismissal of employees [52, 86],

ii. increase in transaction costs [52],

iii. decrease in transaction volumes [52, 77, 88].

b. result in cost shifting by banks, for example:

i. moving operations from the EU to Asian countries [61, $77,88]$,

ii. distorting activities of international banks [43].

c. increase price volatility in the financial market $[52,88]$.

d. reduce the revenues necessary for providing financial support to the banking sector and its restructuring [52].

e. change the structure of the financial market [52].

f. cause economic disturbance $[2,77]$.

g. increase corporate income taxes paid by international banks to levels that apply to domestic banks operating in the same banking market (Huizinga et al., 2012).
Proponents of additional taxation in the banking sector argue that new regulations could:

a. reduce the probability of another financial crisis [61].

b. decrease the amount of spending on bank bailouts [22, $34,92]$.

c. increase the resilience of the financial system $[58,66]$.

d. correct financial market imperfections $[19,30,58]$.

e. reduce the vulnerability of financial markets [57].

f. enhance the efficiency and stability of financial markets [65].

g. reduce public debt $[32,33]$.

h. curb non-fundamental short-term trading in financial markets by raising the cost of financial transactions [56].

The taxation of the financial sector is a very contentious issue. Consequently, it is not implemented by virtue of a directive (requiring the unanimity of all EU member states), but through enhanced cooperation (only among willing countries) [27]. Therefore, financial sector taxes differ between countries. In the following subsection, three forms of financial institution taxes are analyzed: bank levy, FTT and FAT.

\section{Bank levy}

In 2010, the IMF advanced the idea of levies on banks' balance sheets, either on assets or on liabilities. The aim was to increase revenue from the financial sector, while enhancing financial stability by incentivizing banks to adopt less risky capital structures, engage in less risky activities in order to avoid systemic risk. This means that the bank levy might discourage banks to recklessly extend loans to illiquid firms and the block shareholders excessively take on debt financing without due regard to financial distress risk [26]. Reducing such risky activities is intended to reduce systemic risk and due to the European Central Bank [28], systemic risk is the possibility of an institution failing to honor its obligations, prompting the same failure on the part of other participants and causing wider effects due to liquidity and credit constraints. Ultimately, the stability of the financial system is jeopardized. Similarly, systemic financial risk is defined by Lehar [55].

Therefore, bank levy was considered the first best solution for the financial sector and it was linked to a credible and effective resolution mechanism. The main aim of the bank levy is a levy collected to bear the fiscal cost of any potential government support needed by the sector. Bank levy can help reduce the risk or raise money for repair funds (or state budget) during a crisis [22]. To that end, several countries have proposed or established bank levies to recoup the costs borne as a result of the recent crisis and create a buffer against future crises. Proposals differ when it comes to the 
Fig. 1 Bank levy models of European countries

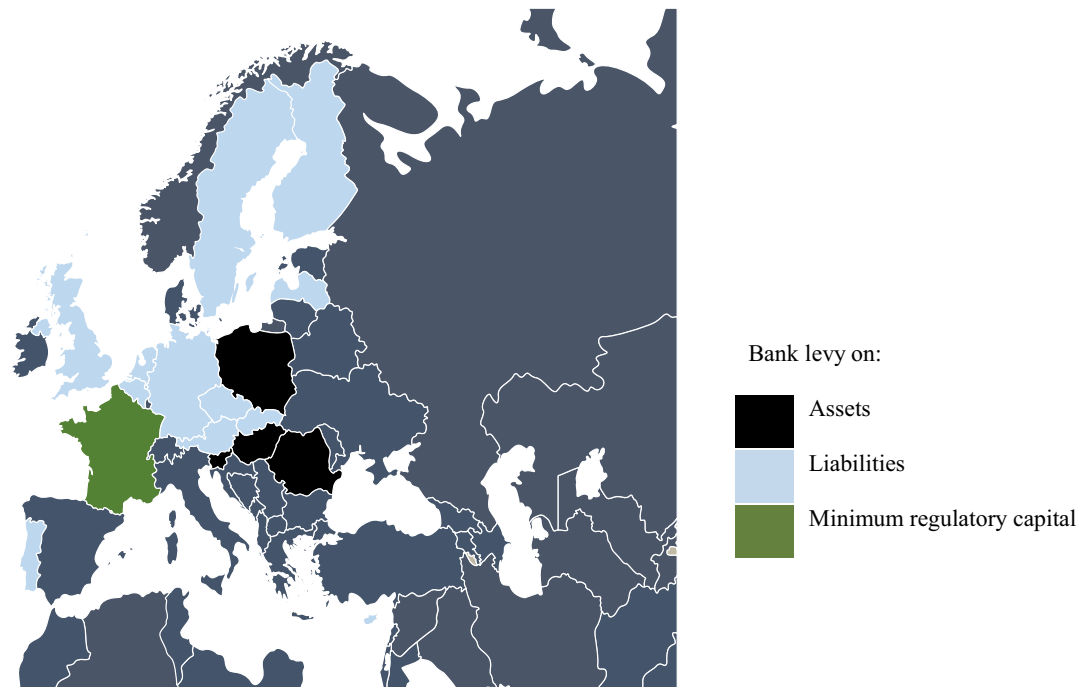

construction and purpose of the accumulated proceeds. On the one hand, all proceeds can be collected in a fund. On the other hand, they can form part of the general government revenue. The bank levy generally is paid by almost all financial institutions and initially reflects individual institutions' riskiness and contributions to systemic risk related size, interconnectedness and substitutability, among others and variations in the overall risk over time [19].

Notably, the base of the levy includes balance sheet measures. The composition of the balance sheet of financial institutions captures risk considerations better than other variables (such as the volume of financial transactions or profitability). In deciding the components of the balance sheet to be included, two issues arise: the base should be represented by assets or liabilities and taxes should be broad or narrow (e.g., include or exclude off-balance sheet items). Moreover, the levy, which is closely linked to the resolution mechanism and its monitoring and collection would likely be best if it is subject to the overarching guidelines of the resolution agency [45].

A bank levy is a tax on specific elements of the balance sheets of financial institutions and takes many forms. The most common levy design adopted by 11 countries (Austria, Belgium, Cyprus, Germany, the Netherlands, Latvia, Portugal, Romania, Slovakia, Sweden and the UK) taxes some portion of bank liabilities. While levies are conceptually similar, they vary along several dimensions. First, most of the levies are in total the liabilities net of own funds and customer deposits that are guaranteed under a deposit insurance scheme. However, two countries (Cyprus and Portugal) include insured deposits in the levy base. Second, the majority of levies treat short-term and long-term liabilities symmetrically, but two countries (the Netherlands and the UK) apply a reduced rate to liabilities with a maturity period exceeding one year. Third, a flat rate is applied to most of the levies, but four countries (Austria, Germany, the Netherlands and the UK) have a progressive rate structure in which small banks are either taxed at lower rates than large banks or not taxed at all. Finally, unlike the other countries, the UK has adopted rules that narrow the taxable base; most notably, they allow for the netting of gross assets and liabilities against the same counterpart and grant a deduction for highly liquid assets [23].

Four countries (France, Hungary, Slovenia and Poland) have adopted bank levies that are conceptually quite different from the design described above. In France, the taxable base is the minimum amount of capital necessary to comply with regulatory requirements. In Hungary, bank levy is calculated on total assets (net of interbank lending). In Slovenia, the taxable base is total assets with no deductions, but the levy is not due if either the level of lending to the non-financial sector or its growth exceed the threshold [23]. In Poland, bank levy is calculated based on total assets. Figure 1 presents the extent of application of bank levy models in Europe.

The figure above shows that most of the European countries introduced bank levy on liabilities. Table 1 summarizes levy structures in European countries.

\section{Financial transaction tax}

In September, 2011, the European Commission suggested FTT as the preferred method for European governments to apply in their financial systems to recoup some of the losses incurred during the GFC [32]. FTT would be levied on all financial transactions in both organized markets and for over-the-counter transactions. It would be levied at a relatively low rate and would be applicable each time the underlying asset is traded (European Commission, 2010). 


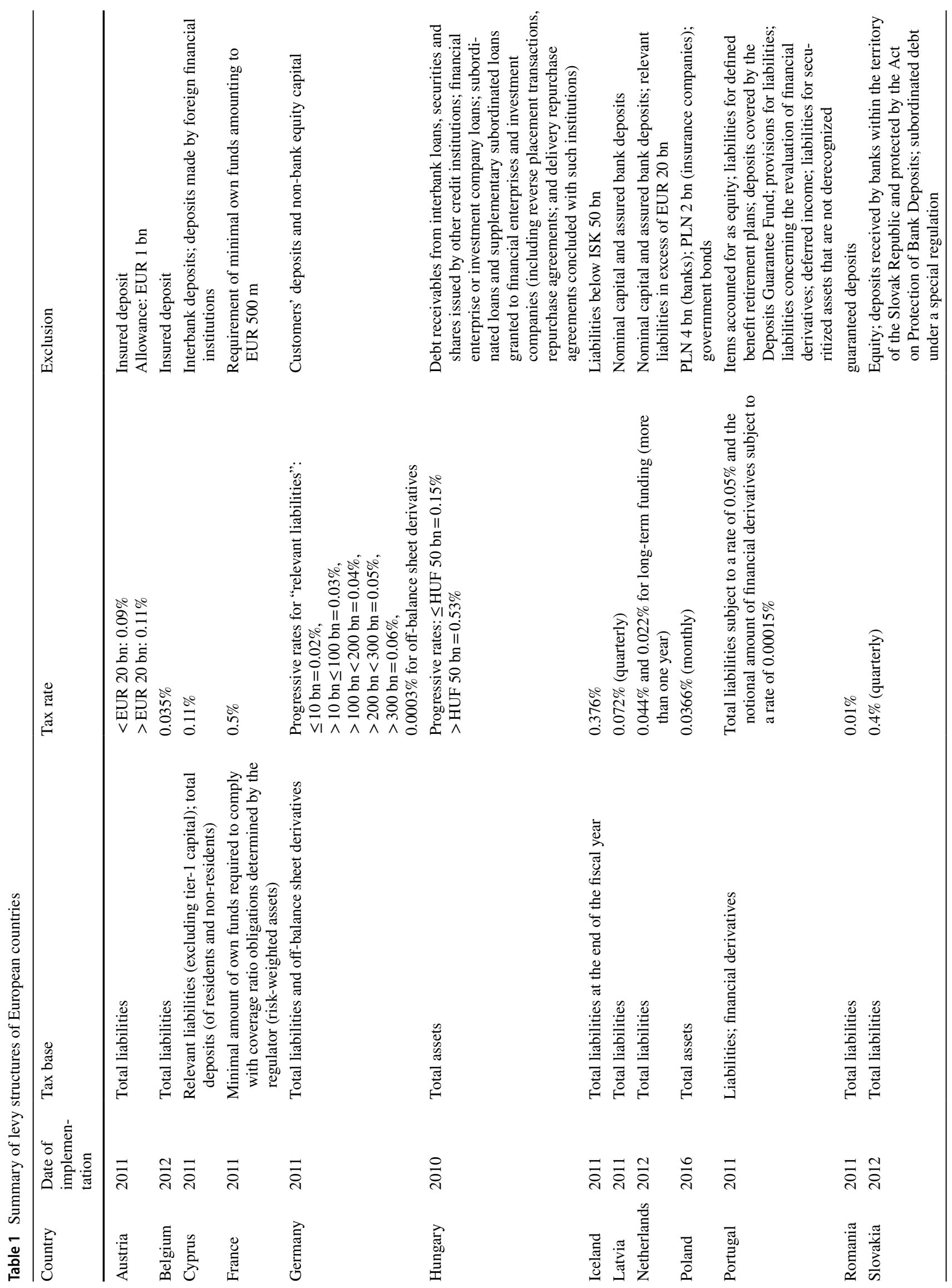




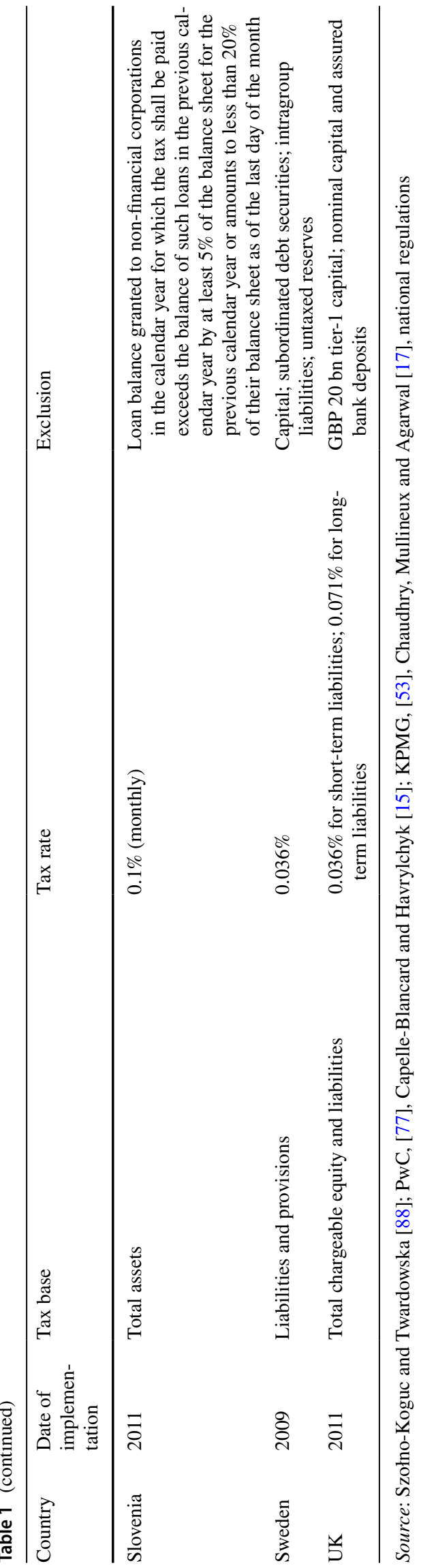

The notion of FTT as an instrument for reducing speculation and stabilizing financial markets gained popularity following the publication of Tobin's seminal work [46]. Its originally intended effects include decreased volatility and increased market efficiency, as speculators (noise traders) are forced to reduce trading frequency. Scientific research on the impact of FTTs essentially began in the 1990s, with contributions from many authors [e.g., 3, 47, 48, 84, 85]. FTTs have been popular in less developed countries as a way to raise significant revenue from a small number of relatively mature financial entities [39].

One common type of FTT is the STT. It applies to the issuance and/or trading of financial securities and potentially includes stocks, debt and related derivatives. Moreover, STT is a policy tool commonly used throughout the world. STTs have been present in major financial markets like Japan, the UK, Germany, Italy and France; smaller OECD economies like Australia, Austria, Belgium, Denmark, Greece and Ireland; and many emerging economies like Chile, China, India and Malaysia. STT has been considered an important regulation device, but when it comes to its impact on financial markets, no consensus has been reached, either through theoretical analysis or empirical studies. In general, its proponents argue that STT can generate revenues for the government, reduce market volatility and enhance market efficiency by curbing short-term noise trading and unproductive speculation activities [83, 84]. Opponents (e.g., [36]) focus on the fact that STT would result in lower asset prices, increased cost of capital for businesses and lower return on savings. They also fear that it would reduce liquidity, thus producing greater price volatility and interfering with price discovery, thus leading to widespread tax evasion and distortion of financial markets.

Another type of FTT is the currency transaction tax (CTT). It applies to transactions involving foreign exchange and related derivatives. Bank transaction taxes or bank debit taxes, which are common in Latin American and Asian countries, apply to deposits and withdrawals from bank accounts, often including checking accounts. In addition, some countries tax insurance premiums, real estate transactions and additions to business capital. FTT can also apply to commodities, although such proposals are yet to be formulated [62].

Overall, proponents advocate FTT because it would:

a. generate substantial revenues at low rates, since the base, which is the value of financial transactions, is enormous;

b. curb speculative short-term and high-frequency trading which would then contain the phenomenon of diversion of valuable human capital into pure rent-seeking activities of little or no social value; 
c. reduce asset price volatility and bubbles, which hurt the economy by creating unnecessary risks and distorting investment decisions;

d. encourage patient capital and longer-term investments; and

e. help recoup the costs of financial sector bailouts as well as the costs of the financial crisis on the rest of the economy.

On the other hand, opponents argue that:

a. FTT, as a non-creditable tax on intermediate inputs in the production process, could cascade, resulting in unequal impacts across assets and sectors, which would distort economic decisions [10],

b. progressivity of FTT is overstated, as much of the tax could fall on the retirement savings of middle-class workers and retirees [39].

\section{Financial activity tax}

The third type of tax analyzed by the IMF [45] is the FAT, which is a tax on profits and total remuneration of financial institutions and can be considered VAT. The aim of introducing FAT was to increase market efficiency and reduce excessive risk-taking behavior [88]. FAT would place a burden on profits and remunerations and its role would be similar to the role of VAT [19]. FAT would be similar to a tax on rents in the financial sector if the tax base comprised only high levels of remuneration and the profit component were defined properly, excluding normal levels of return on capital [19]. The European Commission [32] considered three versions of FAT:

a. The addition method FAT, a broad version of FAT, in which the tax base would be the profit, minus capital formation, plus wages. In other words, the tax base would be the net cash flow, that is, with full expensing of capital investment and deduction of financial costs. This tax has been used in some countries in sectors exempted from VAT (also known as the addition method VAT). Therefore, FAT can help reduce high wages in the financial sector.

b. The rent-taxing FAT would tax rents only; that is, remuneration and cash flow profit above a threshold, defining which has proved to be a problem.

c. The risk-taxing FAT would tax excess returns resulting from unduly risky activities. The threshold is set at a level based on what is considered as excessive return to (average) equity. This version of FAT would discourage excessive risk-taking [32].

\section{Theory of bank levy}

One of the aims of bank levies is to modify the incentives of banks' management and owners and thus persuade them to take into account the bank's contribution to systemic risk [7]. Therefore, many researchers decided to examine whether the objective was achieved. Unfortunately, the research results show a contradictory effect. Devereux et al. [23] find that banks reduce their leverage, but also increase risk-taking based on the average risk weight after the bank levy introduction. Puławska [74] demonstrates that the Hungarian bank levy on assets has a negative impact on the financial sector's stability. Potter [73] shows that the Australian levy might cause a mispricing of risk, encouraging banks to increase the use of more risky borrowings while discouraging the use of some less risky borrowings, particularly long-term wholesale borrowings. On the other hand, the German bank levy on liabilities might decrease credit risk [74]. Schweikhard and Wahrenburg [80] estimate the hypothetical amount of bank levy payments during the financial crisis and weigh it in terms of the funding benefit of systemically influential banks through government guarantees. They find that levies lead to partial internalization of systemic risk. Others have claimed that bank levies allow the taxing of potential economic rents enjoyed by the financial sector, owing to the implicit and explicit state guarantees [15]. In his research, Diemer [25] shows that bank levy on secured debt can prevent banks from excessive risk-taking only if this charge is performance-unrelated. A bank levy on risk-weighted assets can be even more effective than a levy on secured debt if banks are well-capitalized and the bank levy on unsecured debt does not affect the risk-taking of transparent banks, but it decreases the risk-taking of opaque banks.

Recent studies have indicated that banks might decrease the tax burden by changing either their balance sheet structure or their business models [9]. For example, Buch et al. [9] suggested that banks try to attract funds that are not subject to the levy. Their results also indicated that, in the longer run, banks can change their business models to more retailbased funding in order to pay lower taxes [9]. The studies investigating longer periods confirm this result; the results from Puławska [76] clearly point to the negative effect of bank levy introduction on the ROA of larger Hungarian commercial banks and of smaller commercial banks in Germany. Moreover, the results showed that the introduction of the bank levy did not influence loan activity in Hungary. However, it decreased the value of the loans from German commercial banks. The results showed that commercial banks in Hungary prefer to restructure their balance or shift assets among different locations or entities to decrease the bank levy. Passing through the bank levy to customers and restructuring the balance sheet have been identified by other 
researchers also as methods to avoid paying the bank levy. For example, Mauro [63] predicts that a levy on liabilities raises the lending rate in the case of a full pass-through. Potter [73] shows that, if the big banks have substantial market power-as the government implies-the banks could just use this power to ensure that the levy is fully passed on to customers. Kogler [51] noticed that the lending rate strongly increases in concentrated markets, whereas the pass-through is weak for well-capitalized banks.

Furthermore, other studies show that, inter alia, the value of banks affected by the bank levy decreases. This suggests that the burden of the levy is borne partly by affected bank shareholders [18]. Haskamp [37] observed the spillover effects of the bank levy from levy-paying commercial banks to commercial banks in the German financial sector that are not obligated to pay the bank levy. He claimed that an increase in the lending rates of commercial banks paying the bank levy caused an increase in the lending rates of institutions exempt from the bank levy (spillover effect). He noticed the indirect effect on one-third of the analyzed sample. Puławska [76] also shows that Hungarian commercial banks decreased the value of the paid bank levy after the Basel III introduction. On the other hand, the results also showed that the value of the paid bank levy in German commercial banks increased after the Basel III and SRF introduction, especially in larger banks. Moreover, the introduction of bank levies leads to lower leverage as the cost of debt rises. The higher the corporate income taxes are, the weaker this reduction in the leverage is [6].

In conclusion, the results of the studies vary because they refer to different countries and therefore different bank levy models.

\section{Global bank levy}

Global banks have expanded their international activities during the past decade. The consequences of this increased internationalization of banking have been debated [16]. Economists argue that this effect will not reverse in the near future [21]. Considering that international banks restructure their balance sheets or move assets within the group to countries in which other elements of balance sheets are subject to levy [76], the bank levy does not fulfill its role. Therefore, it is argued that the model of the bank levy should be the same across the European countries in order to achieve its purpose. The International Monetary Fund [45] recommends in its report that the bank levy should be uniform for all EU countries and preferably should be based on the banks' liabilities, excluding customer deposits. A global treatment of bank levies will ensure that banks are levied in a consistent and equal form.

The increasing integration that characterizes the current period of globalization has sparked a heated debate about the role that standardized, global law should (or could) play in the process [4, 5]. A good example of globally introduced banking regulation that regulators could rely on is Basel. Global administrative law inherent in the Basel process could be a model for international rule-making with greater accountability and legitimacy. At the international level, the Basel committee has engaged in a relatively open process akin to a notice and comment rule-making in developing international capital standards and has improved its transparency. At the domestic level, central banks and national bank regulators have enmeshed the Basel standards in the domestic notice and comment rule-making process, enhancing the legitimacy of the international process through local procedural protections [5].

In addition, the introduction of a uniform internationally accepted model of bank levy could ensure that forthcoming banking regulations such as the SRF or Basel III do not interfere with the bank levy established in certain countries. The recent study indicated that, among Hungarian commercial banks, the value of the paid bank levy decreased after the Basel III introduction. On the other hand, the result showed that, in German commercial banks, the value of the paid bank levy increased after the Basel III and SRF introduction, especially in larger banks. These dependencies are due to the positions in the financial statements affected by these regulations [76]. This is another indication that the bank levy should be considered globally. The interaction among international, transnational and domestic administrative procedures might generate a model of bank levy that promotes accountability and legitimacy in the global administrative space [5].

\section{Assessment of bank levy models}

Recently, many European countries have decided to apply a bank levy. Although levy design has been subject to legislative debate, an increasing number of countries are considering its introduction or a change to the existing model. The recent trend of levying taxes on bank operations has raised the question of its impact on the performance and activities of domestic banking systems. Taxing bank operations could disrupt bank activities and negatively affect a country's economic situation. Therefore, it is important to consider the most appropriate bank levy model. Table 2 presents the advantages and disadvantages of each possible financial sector taxation model. 
Table 2 Advantages and disadvantages of possible bank levy models

\begin{tabular}{ll}
\hline Tax base & Advantages \\
\hline Assets & $\begin{array}{c}\text { Reflects the size and scale of banks' operating } \\
\text { revenues }\end{array}$ \\
Risk-weighted assets & \\
& $\begin{array}{l}\text { Reflects the size and scale of banks' operating } \\
\text { revenues } \\
\text { Limits credit risk }\end{array}$
\end{tabular}

Limits credit risk

Off-balance risk-weighted assets and liabilities

Reflects the scale of risks of banks' activity

Equity and liabilities

Payables
Disadvantages

Omits off-balance sheet activities

Ignores risks related to particular assets

Depends on the accepted accounting principles

Secured assets are also taxed

Limits banking activity

Limits interbank transactions

Risk of increased loan rates and decreased deposit rates

Omits off-balance sheet activities

Ignores risks related to particular assets

Fails to consider the financial condition of banks

Depends on the accepted accounting principles

Risk of increased loan rates and decreased deposit rates

Fails to consider risks other than credit risks Insufficiently reflects banks' risk profiles

Assessment of the tax does not depend on the bank's financial condition (including profitability)

Risk of increased loan rates and decreased deposit rates

Omits obligations resulting from off-balancesheet operations

Fails to consider the risk

does not depend on the tax on banks' financial condition

Depends on the accepted accounting principles (e.g., provisions including deferred revenue and accrued expenses)

Tax is imposed on liabilities, which are a stable source of financing and an instrument of market discipline

Risk of curbing bank activities (including a slowdown of credit activity due to insufficient access to funding)

The inclusion of interbank loans may interfere with the market

Guaranteed deposits are taxed

The "cash" item of the balance sheet, which is the basis for determining the minimum amount of reserves and guaranteed funds, is taxed

Both long-term liabilities and assets are taxed

Does not depend on the bank's financial condition (including risk and profitability levels)

Subordinated liabilities, which represent a reliable source of financing and an instrument of market discipline, are taxed

Items created as a result of accepted accounting principles are subject to taxation

Risk of curbing bank activities (including a slowdown of credit activity due to insufficient access to funding)

Risk of increased loan rates and decreased deposit rates 
Table 2 (continued)

\begin{tabular}{|c|c|c|}
\hline Tax base & Advantages & Disadvantages \\
\hline $\begin{array}{l}\text { Liabilities and equity without capital and } \\
\text { insured deposit }\end{array}$ & $\begin{array}{l}\text { Positions that are a hedge of risk (equity) are } \\
\text { not taxed } \\
\text { Positions representing fundamental banking } \\
\text { operations are not taxed } \\
\text { Incentives to finance activities in a sustainable } \\
\text { manner, which should increase the recapi- } \\
\text { talization of the banking sector and result in } \\
\text { a focus on traditional, basic banking services }\end{array}$ & $\begin{array}{l}\text { Does not depend on the bank's financial condi- } \\
\text { tion (including risk and profitability levels) } \\
\text { Subordinated liabilities, which represent a reli- } \\
\text { able source of financing and an instrument of } \\
\text { market discipline, are taxed } \\
\text { Items created as a result of accepted accounting } \\
\text { principles are subject to taxation } \\
\text { Risk of increasing the cost of access to external } \\
\text { sources of financing } \\
\text { Risk of curbing bank activities (including } \\
\text { slowdown of credit activity due to insufficient } \\
\text { access to funding) }\end{array}$ \\
\hline $\begin{array}{l}\text { Balance sheet total and off-balance sheet } \\
\text { liabilities }\end{array}$ & $\begin{array}{l}\text { Comprehensively reflects the scale of banks' } \\
\text { activities } \\
\text { Riskiest items (off-balance sheet) are taken } \\
\text { into account }\end{array}$ & $\begin{array}{l}\text { All remarks as to the sum of assets/liabilities } \\
\text { (except for the omission of off-balance sheet } \\
\text { operations) }\end{array}$ \\
\hline Total capital requirement & $\begin{array}{l}\text { Reflects the scale of banks' activities } \\
\text { Reflects the level and nature of risks }\end{array}$ & $\begin{array}{l}\text { The position that is secured bank's own funds is } \\
\text { subject to taxation } \\
\text { The position that is the basis for determin- } \\
\text { ing the annual fee for the BFG is subject to } \\
\text { taxation } \\
\text { The financial condition is not taken into account }\end{array}$ \\
\hline Profit & $\begin{array}{l}\text { Partially reflects the scale of banks' activities } \\
\text { Tax is based on banks' financial condition }\end{array}$ & $\begin{array}{l}\text { Fails to take into account the risk associated } \\
\text { with business activity } \\
\text { Can decrease efficiency (overestimation of } \\
\text { costs) } \\
\text { Decreases banks' attractiveness from the per- } \\
\text { spective of investors }\end{array}$ \\
\hline Transaction (turnover of financial instruments) & $\begin{array}{l}\text { Imposed on risky transactions } \\
\text { Could reduce systemic risk } \\
\text { Replaces VAT, making tax levies fairer }\end{array}$ & $\begin{array}{l}\text { Can distort the value of financial instruments } \\
\text { Systemic risk is only partially addressed- dif- } \\
\text { ficulties in reconciling the tax base (including } \\
\text { the valuation of derivatives) } \\
\text { Risk of arbitration; transition to unregulated } \\
\text { areas } \\
\text { Reduction (or increased costs) of the potential } \\
\text { hedging of risk related to derivatives }\end{array}$ \\
\hline Banking financial activities & $\begin{array}{l}\text { Concerned with high-risk transactions } \\
\text { Increases tax levies on banks, compensating } \\
\text { for the negative effects of the VAT exemp- } \\
\text { tion } \\
\text { Depending on the adopted model, it might } \\
\text { discourage from excessive risk-taking } \\
\text { Depending on the adopted model, it could } \\
\text { promote increased equity financing }\end{array}$ & $\begin{array}{l}\text { Conventional banking operations are also taxed, } \\
\text { thus limiting banks' growth } \\
\text { Risk of increased loan costs and decreased } \\
\text { deposit prices (tax shifting) } \\
\text { Risk of arbitration } \\
\text { loss of competitiveness by banks (compared to } \\
\text { others financial, para-financial or non-finan- } \\
\text { cial entities), } \\
\text { Increased systemic risk as a result of the taking } \\
\text { over of banking services by non-supervised } \\
\text { substitutes } \\
\text { Difficulties in estimating the tax base }\end{array}$ \\
\hline $\begin{array}{l}\text { Innovative financial instruments (e.g., deriva- } \\
\text { tives) }\end{array}$ & $\begin{array}{l}\text { Concerned with high-risk transactions } \\
\text { Fails to differentiate between entities }\end{array}$ & $\begin{array}{l}\text { Difficulties in defining "innovative" operations } \\
\text { or instruments } \\
\text { The risk of slowdown in the progress and devel- } \\
\text { opment of the financial sector } \\
\text { Difficulties in reconciling the tax base (includ- } \\
\text { ing the measurement of derivative instru- } \\
\text { ments) }\end{array}$ \\
\hline
\end{tabular}




\section{Conclusions}

Regulators responded to the GFC with a number of regulations intended to prevent financial crises in the future. One of the earliest introduced regulations was the bank levy, which is described in detail in this article. In the paper, we present the history of taxation of the financial sector, the models introduced in different European countries, the advantages and disadvantages of each of the possible solutions, the results of studies on the impact of the new levy on the behavior of the financial sector and recommendations on how the levy should be structured.

The taxation of financial sector is not an entirely new concept. Regulators recall their advantages at the time of crises. An example is the idea of taxing the financial sector after the Great Depression that was advanced by Keynes [50] or after the breakdown of the Bretton Woods, which was proposed by Tobin [46]. Thus, the analysis of post-GFC bank levies is highly relevant with respect to the current turbulent times caused by the COVID-19 pandemic. However, today, the bank levy will not be implemented by virtue of a directive (requiring the unanimity of all EU member states), but through enhanced cooperation (only among willing countries) [27]. Therefore, model of bank levy differ between countries, as a consequence, it does not fully fulfill its role. Studies show that banks are shifting items off their balance sheets to countries where bank levies are lower or not yet implemented $[9,51,76]$. Additionally, research shows that some bank levy models encourage banks to accept more risk in order to avoid paying the levy, rather than discouraging it $[23,73]$. The analysis of the advantages and disadvantages of the various bank levy models presented in this article concludes that a bank levy applied to select liabilities (such as wholesale funding, short-term debt or foreign funding) could be the appropriate solution. However, it is important to exclude equity (so not to discourage capital accumulation). This bank levy base was also recommended by IMF [45]. However, it states that the base and rate should: (i) avoid any possible arbitrage, (ii) reflect appropriately risks, (iii) take into account the systemic nature of certain financial entities, (iv) be based on the possible amounts that could be needed if resolution becomes necessary and (v) avoid competitive distortions [45]. A broad base on the liability side of the balance sheet may be preferable, as it allows a lower rate for any given amount of revenue and so limits the risk of unintended distortion. Such a base would also reflect that the cost of resolution arises from the need to support liabilities.

In addition, in order to avoid tax shifting within a group, it is worth considering the introduction of a single global tax model across Europe, as was the case with the Basel regulation. Also, IMF [45] agreed that a global solution might be the most appropriate. Given the close integration of global financial markets, agreement on the broad principles underlying measures will be beneficial and can facilitate crossborder resolution.

Based on the model proposed above, there is a direction for further research. Such research could examine the impact of bank levy on liabilities in the performance and operation of the banking sector. Furthermore, economists have recently argued that the levy could negatively affect the interbank market. Heider, Hoerova and Holthausen [38] and Acharya and Merrouche [1] observe that, given high levels of uncertainty, banks prefer to maintain high reserves to lending to each other, even at the risk of generating lower profits. This could lead to a collapse of the interbank market as banks become unable to acquire funds. Therefore, the second research direction involves determining if the bank levy on bank assets limits banks' activities in the interbank market.

Funding This research was financed by the National Science Center, Poland, grant number UMO-2017/25/N/HS4/01912.

\section{Declarations}

Conflicts of interest On behalf of all authors, the corresponding author states that there is no conflict of interest.

Availability of data and material The data that support the findings of this study are available from the corresponding author upon reasonable request.

\section{References}

1. Acharya, Viral V., and Ouarda Merrouche. 2012. Precautionary Hoarding of Liquidity and Interbank Markets: Evidence from the Subprime Crisis. Review of Finance 17 (1): 107-160.

2. Baker, Dean. 2008. The Benefits of Financial Transactions Taxes. Center for Economic and Policy Research 15 (166): 1-9.

3. Baltagi, Badi H., Dong Li, and Qi. Li. 2006. Transaction Tax and Stock Market Behavior: Evidence from an Emerging Market. Empirical Economics 31 (2): 393-408.

4. Barr, Michael S., and Reuven S. Avi-Yonah. 2004. Globalization, Law \& (and) Development: Introduction and Overview. Mich. J. Int'l L. 26: 1.

5. Barr, Michael S., and Geoffrey P. Miller. 2006. Global Administrative Law: The View from Basel. European Journal of International Law 17 (1): 15-46.

6. Bremus, Franziska, Kirsten Schmidt and Lena Tonzer. 2020. "Interactions between Bank Levies and Corporate Taxes: How Is Bank Leverage Affected?" Journal of Banking \& Finance, 105874.

7. Buch, C., Lena Tonzer and Benjamin Weigert. 2017. "Assessing the Effects of Regulatory Bank Levies." VOX CEPR Policy Portal. 2017. https://voxeu.org/article/assessing-effects-regul atory-bank-levies.

8. Buch, C., Tobias Körner, and Benjamin Weigert. 2015. Towards Deeper Financial Integration in Europe: What the Banking 
Union Can Contribute. Credit and Capital Markets-Kredit Und Kapital 48 (1): 11-49.

9. Buch, Björn Hilberg and Lena Tonzer. 2016. "Taxing Banks : An Evaluation of the German Bank Levy." Journal of Banking and Finance 72 (C): 52-66. https://doi.org/10.1016/j.jbankfin. 2016.07.010.

10. Burman, Leonard E., William G. Gale, Sarah Gault, Bryan Kim, Jim Nunns, and Steve Rosenthal. 2016. Financial Transaction Taxes in Theory and Practice. National Tax Journal 69 (03): 171-216.

11. Campbell, John Y and Kenneth A Froot. 1994. "International Experiences with Securities Transaction Taxes." In The Internationalization of Equity Markets, 277-308. University of Chicago Press.

12. Cannas, Giuseppina, Jessica Cariboni, Massimo Marchesi, Gaëtan. Nicodème, Marco Petracco Giudici, and Stefano Zedda. 2014. Financial Activities Taxes, Bank Levies and Systemic Risk. European Commission Taxation Papers. https://doi.org/ $10.2778 / 3498$.

13. Capelle-Blancard, Gunther and Olena Havrylchyk. 2013. "The Ability of Banks to Shift Corporate Income Taxes to Customers." CEPII, WP 09.

14. Capelle-Blancard, Gunther and Olena Havrylchyk. 2015. "The Impact of the French Securities Transaction Tax on Market Liquidity and Volatility." Centre d'Economie de La Sorbonne 33 (April 2013): 106-12.

15. Capelle-Blancard, Gunther and Olena Havrylchyk. 2017. "Incidence of Bank Levy and Bank Market Power." Review of Finance 21 (3): 1023-46.

16. Cetorelli, Nicola, and Linda S. Goldberg. 2011. Global Banks and International Shock Transmission: Evidence from the Crisis. IMF Economic Review 59 (1): 41-76.

17. Chaudhry, Sajid Mukhtar, Andrew Mullineux, and Natasha Agarwal. 2015. Balancing the Regulation and Taxation of Banking. International Review of Financial Analysis 42: 38-52. https://doi.org/10.1016/j.irfa.2015.01.020.

18. Chronopoulos, Dimitris K, Anna L Sobiech and John O S Wilson. 2018. "The Australian Bank Levy: Do Shareholders Pay?" Finance Research Letters 28: 412-15. https://doi.org/10.1016/j. frl.2018.06.010.

19. Claessens, Stijn, Michael Keen and Ceyla Pazarbasioglu. 2010a. "Financial Sector Taxation: The IMF's Report to the G-20 and Background Material." Washington.

20. Crotty, James. 2008. "Structural Causes of the Global Financial Crisis: A Critical Assessment of The." New Financial Architecture".-Economics Department Working Paper Series, no. 16: 61 .

21. Crouch, Colin. 2009. Privatised Keynesianism: An Unacknowledged Policy Regime. The British Journal of Politics and International Relations 11 (3): 382-399.

22. Dec, Paweł and Piotr Masiukiewicz. 2013. Podatek Bankowy. Warsaw: C.H.Beck.

23. Devereux, Michael, Niels Johannesen and John Vella. 2015. "Can Taxes Tame the Banks ? Evidence from the European Bank Levies." Saïd Business School, Research Papers, no. April.

24. Devereux, Michael, John Vella, Niels Johannesen, Michael P Devereux, Niels Johannesen and John Vella. 2013. "Can Taxes Tame the Banks ? Evidence from European Bank Levies." Working Paper Series-Oxford University Centre for Business Taxation WP $13 / 25$

25. Diemer, Michael. 2017. Bank Levy and Risk-Taking. Review of Financial Economics 34: 10-32. https://doi.org/10.1016/j.rfe. 2017.06.001.

26. Du, Julan, and Yi. Dai. 2005. Ultimate Corporate Ownership Structures and Capital Structures: Evidence from East Asian
Economies. Corporate Governance: An International Review 13 (1): $60-71$

27. Dvořáková, Veronika, and Danuše Nerudováa. 2014. Financial Transaction Tax : Can It Be Sufficient Resource of EU Budget When Introduced through Enhanced Cooperation ? Procedia Economics and Finance 12: 453-461. https://doi.org/10.1016/S22125671(14)00367-0.

28. ECB. 2009. "Financial Stability Review.” December. 2009. https:// www.ecb.europa.eu/pub/pdf/fsr/financialstabilityreview200912en. pdf.

29. ECB. 2016. "Opinion on a Tax for Certain Financial Institutions." European Central Bank CON/2016/1: 42-45.

30. European Commission. 2010a. "Communication From the Commission to the European Parliament, the Council, the European Economic and Social Committee and the Committee of the Region." Europe 2020 Flagship Initiative Innovation Union 1161 (546): 1-9.

31. European Commission. 2010b. "Financial Sector Taxation." Taxation Papers 25. https://ec.europa.eu/taxation_customs/sites/taxat ion/files/resources/documents/taxation/gen_info/economic_analy sis/tax_papers/taxation_paper_25_en.pdf.

32. European Commission. 2011. "Impact Assessment Accompanying the Document Proposal for a Council Directive on a Common System of Financial Transaction Tax and Amending Directive 2008/7/EC.” Brussels: European Commission.

33. European Commission. 2013. Proposal Fo Council Directive Implementing Enhanced Cooperation in the Area of Financial Transaction Tax. Brussels: European Commission. https://eur-lex. europa.eu/legal-content/EN/TXT/?uri=CELEX\%3A52013PC0 071.

34. European Commission. 2015. "Tax Reforms in EU Member States 2015 - Tax Policy Challenges for Economic Growth and Fiscal SustainabilityTax Reforms in EU Member States 2015." INSTITUTIONAL PAPER Economic a (8). https://doi.org/10.2765/ 26069.

35. Fecht, Falko, and Stefan Reitz. 2018. Dealer Behaviour in the Euro Money Market during Times of Crisis. Applied Economics 50 (48): 5204-5219. https://doi.org/10.1080/00036846.2018.14860 14.

36. Habermeier, Karl, and Andrei A. Kirilenko. 2003. Securities Transaction Taxes and Financial Markets. IMF Staff Papers 50 (1): $165-180$.

37. Haskamp, Ulrich. 2016. Spillovers of Banking Regulation: The Effect of the German Bank Levy on the Lending Rates of Regional Banks and Their Local Competitors. Ruhr Economic Papers 664: 1884-1914. https://doi.org/10.4419/86788859.

38. Heider, Florian, Marie Hoerova, and Cornelia Holthausen. 2015. Liquidity Hoarding and Interbank Market Rates: The Role of Counterparty Risk. Journal of Financial Economics 118 (2): $336-354$.

39. Hemmelgarn, Thomas, Gaetan Nicodeme, Bogdan Tasnadi, and Pol Vermote. 2016. Financial Transaction Taxes in The European Union. National Tax Journal 69 (1): 217-240.

40. Hillman, David and Christina Ashford. 2012. "Financial Transaction Tax: Myth-Busting." Stamp Out Poverty March: 1-14. https:// www.world-psi.org/sites/default/files/en_ftt_myth-busting_final. pdf.

41. Hillman, David, Sony Kapoor and Stephen Spratt. 2006. "Teaking the next Step: Implementing a Currency Transaction Development Levy." In Second Plenary Meeting of the Leading Group on Solidarity Levies to Fund Development, December. Oslo.

42. Huizinga, Harry. 2002. A European VAT on Financial Services? Economic Policy 17 (35): 497-534.

43. Huizinga, Harry, Johannes Voget and Wolf Wagner. 2012. "International Taxation and Cross-Border Banking." NBER 
Working Paper Series; National Bureau of Economic Research w18483.

44. Hvozdyk, Lyudmyla, and Serik Rustanov. 2016. The Effect of Financial Transaction Tax on Market Liquidity and Volatility: An Italian Perspective. International Review of Financial Analysis 45: 62-78. https://doi.org/10.1016/j.irfa.2016.01.018.

45. International Monetary Fund. 2010. "A Fair and Substantial Contribution by the Financial Sector." IMF Final Report For the $G$-20 June: $2-70$.

46. James, Tobin, 1978. A Proposal for International Monetary Reform. Eastern Economic Journal 4 (3-4): 153-159.

47. Jones, Charles M., and Paul J. Seguin. 1997. Transaction Costs and Price Volatility: Evidence from Commission Deregulation. The American Economic Review 87 (4): 728-737.

48. Jurgen, Huber, Daniel Kleinlercher, and Michael Kirchler. 2012. The Impact of a Financial Transaction Tax on Stylized Facts of Price Returns - Evidence from the Lab. Journal of Economic Dynamics \& Control 36: 1248-1266. https://doi.org/10.1016/j. jedc.2012.03.011.

49. Keen, Michael. 2011. "The Taxation and Regulation of Banks." IMF Working Paper 11 (206): 1-38.

50. Keynes, John Maynard. 1936. The General Theory of Employment, Interest and Money. Palgrave Macmillan.

51. Kogler, Michael. 2019. On the Incidence of Bank Levies: Theory and Evidence. International Tax and Public Finance 26 (4): $677-718$

52. Koḷesņika, Marija, and Inna Dovladbekova. 2014. Financial Transaction Tax as an Instrument for Banking Sector Regulation in the EU. Economics and Business 25: 48-53.

53. KPMG. 2017. "Special Taxes in the Financial Sector." Kpmg. Com. 2017. https://home.kpmg/content/dam/kpmg/fi/pdf/2017/ 11/Bank levies_Nordic comparison.pdf.

54. Laeven, Luc, Lev Ratnovski, and Hui Tong. 2016. Bank Size, Capital and Systemic Risk: Some International Evidence. Journal of Banking \& Finance 69: 25-34.

55. Lehar, Alfred. 2005. Measuring Systemic Risk: A Risk Management Approach. Journal of Banking \& Finance 29 (10): 2577-2603.

56. Lendvai, Julia, Rafal Raciborski, and Lukas Vogel. 2013. Macroeconomic Effects of an Equity Transaction Tax in a GeneralEquilibrium Model. Journal of Economic Dynamics and Control 37 (2): 466-482. https://doi.org/10.1016/j.jedc.2012.09.010.

57. Li, Hongquan, Mengyun Tang, Wei Shang, and Shouyang Wang. 2013. Securities Transaction Tax and Stock Market Behavior in an Agent-Based Financial Market Model. Procedia Computer Science 18 (January): 1764-1773. https://doi.org/10.1016/J.PROCS. 2013.05.345.

58. Mara, Eugenia-Ramona. 2012. Taxation of Financial Sector After the Crisis in The European Union. Annals of the University of Oradea, Economic Science Series 21 (2): 477-482.

59. Marcinkowska, Monika. 2011. "Dodatkowe Podatki i Opłaty Od Banków-Potrzeby Praktyki i Dylematy Teorii Finansów”. In $K$. Jajuga (Red.), Finanse-Nowe Wyzwania Teorii i Praktyki. Problemy Wiodace, Prace Naukowe UE We Wroctawiu 170: 100-127.

60. Marcinkowska, Monika. 2013. Regulation and Self-Regulation in Banking . In Search of Optimum. Bank i Kredyt, Narodowy Bank Polski 44 (2): 119-158.

61. Masiukiewicz, Piotr, and Pawel, . 2012. Growth, Finance and Regulation. Perspectives of Innovations, Economics \& Business 11 (2): 61-69.

62. Matheson, Thornton. 2011. "Taxing Financial Transactions : Issues and Evidence." IMF Working Paper Fiscal Affairs Department 11 (54): 1-49.

63. Mauro, Beatrice Weder Di. 2010. "Taxing Systemic Risk : Proposal for a Systemic Risk Levy and a Systemic Risk Fund." Presented at the Deutsche Bundesbank.
64. Merrill, Peter. 1997. Taxation of Financial Services under a Consumption Tax, vol. 51104. Washington: American Enterprise Institute

65. Meussen, Gerard. 2011. European Union. A New Tax Strategy for the European Union: FTT and FAT, Realistic or a Bridge Too Far? European Taxation 51 (2-3): 101-104.

66. Millar, Anita. 2012. "Report Prepared for the International Regulatory Strategy Group." The International Regulatory Strategy Group London (March).

67. Morgenson, Gretchen. 2009. "After Huge Losses, a Move to Reclaim Executives' Pay.” Sunday Business, New York Times, February 22 (1): 7.

68. MTI-Hungary. 2020. "Coronavirus: One-off Banking Sector Tax Deductible from Bank Levy, Says Finance Minister.” 2020. https://hungarytoday.hu/coronavirus-hungary-banks-tax-banking/.

69. Osvat, Krisztina and Szabolcs Osvat. 2010. "Bank Tax in Hungary Quick Analysis on a Debated Pioneering Step." ANU Centre for European Studies Working Paper Series 1 (2): 1-10.

70. Pawel, Dec, and Piotr Masiukiewicz. 2011. Bank Tax in the European Union. Editura Europlus Galaţi 2: 91-96.

71. Pigou, Arthur C. 1920. The Economics of Welfare, 4th. London: Macnillam.

72. Pleven, Liam, Serena Ng and Sudeep Reddy. 2009. "AIG Faces Growing Wrath Over Payouts.” The Wall Street Journal. 2009.

73. Potter, Michael. 2017. The Major Bank Levy: We're All Going to Be Hit. Centre for Independent Studies.

74. Puławska, Karolina. 2020a. "Effect of Bank Levy Introduction on Bank Risk-Taking." Available at SSRN 3598944.

75. Puławska, Karolina. 2020b. "Effects of the Bank Levy Introduction on the Interbank Market." International Journal of Finance \& Economics online. https://doi.org/10.1002/ijfe.2180.

76. Puławska, Karolina. 2021. "The Effect of Bank Levy Introduction on Commercial Banks in Europe." Journal of Risk and Financial Management . https://doi.org/10.3390/jrfm14060279.

77. PwC. 2013. "Financial Transaction Taxes : Developing a Strategic Response." 2013. https://www.pwc.com/gx/en/financial-servi ces/financial-transaction-taxes/assets/pwc-financial-transactionstaxes.pdf.

78. Rabatinová, Marcela, and Jana Kušnírová. 2015. The Bank Levies in Slovakia and in Other EU Countries. Bankov é Odvody $v$ SR a $v E U^{4}$ : 1-9.

79. Reinhart, Carmen M., and Kenneth S. Rogoff. 2013. Banking Crises: An Equal Opportunity Menace. Journal of Banking \& Finance 37 (11): 4557-4573. https://doi.org/10.1016/J.JBANK FIN.2013.03.005.

80. Schweikhard, Frederic A and Mark Wahrenburg. 2013. "The Internalization of Systemic Risk : An Analysis of Bank Levy Schemes." SSRN Electronic Journal. https://www.schweikhard. org/papers/Paper_GovInt_L.pdf.

81. SEC. 2015. Fee Rate Advisory \#2 for Fiscal Year 2016. Washington, DC. http://www.sec.gov/\%0Anews/pressrelease/2015-222. html.

82. Silva, Walmir, Herbert Kimura, and Vinicius Amorim Sobreiro. 2017. An Analysis of the Literature on Systemic Financial Risk: A Survey. Journal of Financial Stability 28: 91-114.

83. Song and Zhang. . 2005. Securities Transaction Tax and Market Volatility. The Economic Journal 115 (506): 1103-1120.

84. Stiglitz, Joseph E. 1989. Using Tax Policy to Curb Speculative Short-Term Trading. Journal of Financial Services Research 3 (2-3): 101-115.

85. Summers, Lawrence H., and Victoria P. Summers. 1989. When Financial Markets Work Too Well: A Cautious Case for a Securities Transactions Tax. Journal of Financial Services Research 3 (2-3): 261-286.

86. Susło, Robert. 2010. "Węgierskie Banki Zwalniają Przez 'Brutalny' Podatek.” 2010. https://www.money.pl/banki/wiado 
mosci/artykul/wegierskie;banki;zwalniaja;przez;brutalny;podat ek, 176,0,716208.html.

87. Szołno-Koguc, J., and M. Twarowska. 2014. Taxation of the Financial - an Attempt to Find the Best Solution. Journal of Economics \& Management 18: 179-191.

88. Szołno-Koguc, J., and M. Twarowska. 2015. "Dodatkowe Daniny Publiczne Sektora Finansowego (Banków) - Przegląd Międzynarodowy." ALTERUM Ośrodek Badań i Analiz Systemu Finansowego December: 1-87. http://alterum.pl/uploaded/Ekspe rtyza_-_dodatkowe_daniny_publiczne_sektora_finansowego.pdf.

89. Taylor, Alan M. 2012. "External Imbalances and Financial Crises.” BER Working Papers 18606. http://www.nber.org/papers/ w18606.pdf.

90. Thorndike, Joseph J. 2008. Speculation and Taxation: Time for a Transaction Tax? Tax Notes 119 (6): 1367.

91. Ueda, Kenichi, B. Di Weder, and Mauro. . 2013. Quantifying Structural Subsidy Values for Systemically Important Financial Institutions. Journal of Banking \& Finance 37 (10): 3830-3842.

92. Wollner, Gabriel. 2014. Justice in Finance: The Normative Case for an International Financial Transaction Tax. Journal of Political Philosophy 4 (22): 458-485.
93. Van der Zwan, Natascha. 2014. Making Sense of Financialization. Socio-Economic Review 12 (1): 99-129.

Publisher's Note Springer Nature remains neutral with regard to jurisdictional claims in published maps and institutional affiliations.

Karolina Pulawska is professor assistant in Accounting Department at Kozminski University. As part of the PhD thesis she examined the effect of bank levy introduction in Europe. Her research were financed by National Canter of Science Moreover, she is involved in research project "Audit committee diversity and quality of financial information" which is also granted. In the past, she worked at the National Bank of Poland and in the Ministry of Finance, in Consulting Companies. Today, besides Academia, she works as a Specialist in the Polish Financial Supervision Authority. 